\title{
EBV Infection
}

National Cancer Institute

\section{Source}

National Cancer Institute. EBV Infection. NCI Thesaurus. Code C38759.

An infection that is caused by Epstein-Barr virus. 